\title{
Influence of the EM-A preparation on the structure properties in various mineral soils
}

\begin{abstract}
The aim of the study was the assessment of the influence of EM-A preparation on the properties of soil structure of medium and fine texture. Soil material for the incubation experiment was collected from humus arable horizons of four mineral soils: Gleyic Chernozem (soils A, B and D) and Haplic Fluvisol (soil C). The experiment was conducted in containers of $2000 \mathrm{~cm}^{3}$, where soil material of about $3 \mathrm{~kg}$ was placed and three doses of EM-A were added. After a 12-month incubation, aggregates of $1 \mathrm{~cm}^{3}$ were cut out. Their basic physical properties (density, porosity) were determined, as well as the parameters which characterize the structure: dynamic and static water resistance, secondary aggregation after dynamic and static water resistance and capillary water capacity. The effect of additions of EM-A was not significant for majority of analyzed soil properties.
\end{abstract}

Key words: EM-A preparation, secondary aggregation, minimal and maximal water capacity.

\section{INTRODUCTION}

Texture is a key property that affects the parameters of soil structure. High content of colloids, characteristic to heavy soils, determines the development of permanent monolithical structure, which is not favorable from the agricultural point of view. What is especially harmful, is drying up the soils, as such conditions determine the appearance of solids (aggregates) which cannot be broken. Furthermore, when moisture is too low, such soils dry very fast, they contract and clefts which appear, break plants' roots. As a result of these processes, density grows and porosity decreases, whereas strong moisture of heavy soils results in excessive adhesiveness and lower permeability. Optimal arable moisture of these soils is very limited and therefore, the period for cultivation is short (Świętochowski et al. 1996). Colloquially, these soils are called "minute soils". The alternation of wetting drying cycles may lead to the fall of soil microorganisms' population which may affect structure's composition negatively (Fierer et al. 2003). Nowadays, agriculture gives possibilities for the improvement of soil structure with the application of various structure forming additives. When observing development tendencies in agrotechnics, one may notice the search for alternatives for traditional agriculture such as ecological methods of soil cultivation (Kaczmarek et al. 2007). "EM" technology is believed to be such a chance (Zajączkowski and Sowiński 2001, Higa 2003). The influence of naturally existing microor- ganisms on soil structure has been a subject of a lot of research (Roldan et al. 1994, Schlecht-Pietsch et al. 1994). Their authors concentrated mainly on soils of coarse texture. Less interest is devoted to the influence of soil biocenoses on heavy soils (Neergaard-Bearden and Petersen 2000). The aim of this study was to reveal what impact the implementation of EM-A preparation has on the structure forming parameters on the soils of medium and fine texture.

\section{MATERIALS AND METHODS}

Soil material used for an incubation experiment was collected in May 2014 from a humus arable horizon of four mineral soils: black earths (Gleyic Chernozem) (soils A, B and D) and alluvial soil (Haplic Fluvisol) (soil C) (IUSS Working Group 2015, PSC 2011). The experiment was conducted in containers of $2000 \mathrm{~cm}^{3}$, where soil material of about $3 \mathrm{~kg}$ was placed, after elimination of stones and roots. Altogether, 16 containers were prepared. In case of each of the four soils, apart from control probes (A0, B0, C0, D0), an addition of EM-A cultures (EM-A preparation) was used in three doses (EM I: A1,B1,C1,D1, EM II: A2,B2,C2,D2, EM III: A3,B3,C3,D3). The EM-A preparation consists of lactic bacteria (Lactobacillus casei, Streptococcus lactis), photosynthetic bacteria (Rhodopseudomonas palustrus, Rhodobacter spae), yeast (Saccharomyces albus, Candida utilis), actinomycetes (Streptomyces albus, S. griseus) and molds (Aspergillus oryzae, Mucor hiemalis) (Kacz- 
marek et al. 2008). In conversion to field conditions, the amount reflected spurting of active form concentration of 501 (EM I), 1001 (EM II) and 3001 (EM III) of solution per hectare. EM1 preparation was produced by Greenland Technologia EM company (EM-A $=1$ liter of EM1 concentrate +1 liter of molasses +20 liters of water). Incubation lasted 12 months. During the investigation following parameters were measured: soil moisture, soil temperature and air humidity. The mean soil temperature was: $20,5^{\circ} \mathrm{C}$ (soil A); $20,8^{\circ} \mathrm{C}$ (soil B); $20,7^{\circ} \mathrm{C}$ (soil C) and $20,4^{\circ} \mathrm{C}$ (soil D). The moisture of selected soils was held on a level close to field water capacity. Its average values were as follows: $24.2 \% \mathrm{v} / \mathrm{v}$ (soil A); $26.5 \% \mathrm{v} / \mathrm{v}$ (soil B); 32,1\%v/v (soil C); 20,8\% v/v (soil D). The average air humidity was $52 \%$. After the incubation, cylindrical soil samples of $1 \mathrm{~cm}^{3}$ volume (diameter $11.29 \mathrm{~mm}$, height $10 \mathrm{~mm}$.) - further called aggregates - were cut out. Parameters which characterize soil structure were determined on air dry soil aggregates. The special methods developed in the Department of Soil Science and Land Protection at Poznań University of Life Sciences were used (Rząsa and Owczarzak 1983). The following parameters were determined: static and dynamic water resistance, secondary aggregation, maximal and minimal capillary water capacity. Specific gravity, soil bulk density and total porosity of aggregates were determined by methods widely used in soil science (Van Reeuwijk 2002). The content of total carbon was determined with a Makro Elemental Analyzer (Vario Max CNS). The statistical analysis was conducted with Duncan's test - separately for each soil - at the statistical significance of $\alpha=0.05$. All the analysis were performed in five replications, results presented in tables represent mean values.

\section{RESULTS AND DISCUSSION}

The investigated soils showed the following texture (FAO 1977): loam (soil A), silty loam (soil B), clay (soil C) and sandy loam (soil D) (Table 1). Total carbon content $(\mathrm{Ct})$ did not differ from typical values in soils of similar origin and texture (Rząsa et al. 1999). The lowest content of $\mathrm{Ct}$ was found in the aggregates collected from soil D, whereas the highest from soil B. The former ranged from 12 to $12.1 \mathrm{~g} \cdot \mathrm{kg}^{-1}$, and the latter from 25.4 to 28.9 (Table 1). Application of EM-A did not have a significant impact on the content of Ct. Similar results, including combinations with the addition of various forms of organic matter, were also obtained by Schenck zu Schweinsberg-Mickan and Müller (2009) as well as by van Vliet et al. (2006). An important indicator of soils microbiological activity and,
TABLE 1. Selected physical properties of modelled aggregates

\begin{tabular}{llllll}
\hline $\begin{array}{l}\text { Combi- } \\
\text { nation }\end{array}$ & $\begin{array}{l}\text { Texture } \\
\text { acc to: } \\
\text { FAO }\end{array}$ & $\begin{array}{l}\text { Total } \\
\text { carbon } \\
\text { Ct } \\
{\left[\mathrm{g} \cdot \mathrm{kg}^{-1}\right]}\end{array}$ & $\begin{array}{l}\text { Particle } \\
\text { density } \\
{\left[\mathrm{Mg} \cdot \mathrm{m}^{-3}\right]}\end{array}$ & $\begin{array}{l}\text { Bulk } \\
\text { density } \\
{\left[\mathrm{Mg} \cdot \mathrm{m}^{-3}\right]}\end{array}$ & $\begin{array}{l}\text { Total } \\
\text { porosity } \\
{\left[\mathrm{m3} \cdot \mathrm{m}^{-3}\right]}\end{array}$ \\
\hline $\mathrm{A} 0$ & $\mathrm{~L}$ & $23.6 \mathrm{a}$ & $2.62 \mathrm{a}$ & $1.34 \mathrm{a}$ & $0.488 \mathrm{a}$ \\
$\mathrm{A} 1$ & $\mathrm{~L}$ & $23.8 \mathrm{a}$ & $2.62 \mathrm{a}$ & $1.32 \mathrm{a}$ & $0.496 \mathrm{a}$ \\
$\mathrm{A} 2$ & $\mathrm{~L}$ & $23.7 \mathrm{a}$ & $2.62 \mathrm{a}$ & $1.35 \mathrm{a}$ & $0.485 \mathrm{a}$ \\
$\mathrm{A} 3$ & $\mathrm{~L}$ & $22.9 \mathrm{a}$ & $2.62 \mathrm{a}$ & $1.33 \mathrm{a}$ & $0.492 \mathrm{a}$ \\
\hline $\mathrm{B} 0$ & $\mathrm{SiL}$ & $27.2 \mathrm{a}$ & $2.61 \mathrm{a}$ & $1.20 \mathrm{a}$ & $0.540 \mathrm{~b}$ \\
$\mathrm{~B} 1$ & $\mathrm{SiL}$ & $28.9 \mathrm{a}$ & $2.61 \mathrm{a}$ & $1.28 \mathrm{~b}$ & $0.510 \mathrm{a}$ \\
$\mathrm{B} 2$ & $\mathrm{SiL}$ & $25.4 \mathrm{a}$ & $2.61 \mathrm{a}$ & $1.24 \mathrm{~b}$ & $0.525 \mathrm{a}$ \\
$\mathrm{B} 3$ & $\mathrm{SiL}$ & $26.7 \mathrm{a}$ & $2.61 \mathrm{a}$ & $1.25 \mathrm{~b}$ & $0.521 \mathrm{a}$ \\
\hline $\mathrm{C} 0$ & $\mathrm{C}$ & $21.9 \mathrm{a}$ & $2.63 \mathrm{a}$ & $1.34 \mathrm{a}$ & $0.490 \mathrm{a}$ \\
$\mathrm{C} 1$ & $\mathrm{C}$ & $22.2 \mathrm{a}$ & $2.63 \mathrm{a}$ & $1.36 \mathrm{a}$ & $0.483 \mathrm{a}$ \\
$\mathrm{C} 2$ & $\mathrm{C}$ & $22.9 \mathrm{a}$ & $2.63 \mathrm{a}$ & $1.37 \mathrm{a}$ & $0.479 \mathrm{a}$ \\
$\mathrm{C} 3$ & $\mathrm{C}$ & $22.1 \mathrm{a}$ & $2.63 \mathrm{a}$ & $1.35 \mathrm{a}$ & $0.487 \mathrm{a}$ \\
\hline $\mathrm{D} 0$ & $\mathrm{SL}$ & $11.9 \mathrm{a}$ & $2.64 \mathrm{a}$ & $1.50 \mathrm{ab}$ & $0.432 \mathrm{a}$ \\
$\mathrm{D} 1$ & $\mathrm{SL}$ & $12.1 \mathrm{a}$ & $2.63 \mathrm{a}$ & $1.46 \mathrm{a}$ & $0.445 \mathrm{~b}$ \\
D2 & $\mathrm{SL}$ & $11.2 \mathrm{a}$ & $2.63 \mathrm{a}$ & $1.52 \mathrm{~b}$ & $0.422 \mathrm{a}$ \\
D3 & SL & $11.7 \mathrm{a}$ & $2.63 \mathrm{a}$ & $1.53 \mathrm{~b}$ & $0.418 \mathrm{a}$ \\
\hline
\end{tabular}

Mean values with the same letter do not differ significantly (see Material and Methods).

indirectly, of organic matter mineralization, is a respiration activity of the soil. When analyzing its dynamics, Mayer et al. (2010) did not notice any stimulating influence of EM-A on soil respiration process. However, there are publications which point out a decrease of organic matter after application of EM (Valarini et al. 2003, Zydlik and Zydlik 2008, Tołoczko et al. 2009). Tołoczko et al. (2009) did calculations according to which spurting an arable field with $2 \times 1001$ (two times a year) EM-A/ha might lead to the loss of 7 tones of organic matter. The same authors claim that organic fertilization is necessary to avoid the negative effect of the EM use in the field. On the other hand, some authors inform about a reverse process, i.e. the increase of organic matter after application of EM (Ismail 2013). Probably, the key factor which determines further processes in the organic matter after the application of EM-A preparation is its quality composition and, what follows, easiness of dissolution. Climatic conditions may also have an impact on the organic matter changes. The addition of EM-A did not influence the specific gravity that ranged from 2.61 to $2.64 \mathrm{Mg} \cdot \mathrm{m}^{-3}$ (Table 1). Usually (except of soil B) the same soil reaction after the implementation of the EM-A preparation was observed when bulk density and total porosity of aggregates were concerned (Table 1). No EM-A impact on these traits was observed. The highest bulk density and the lowest total porosity, respectively, $1.53 \mathrm{Mg} \cdot \mathrm{m}^{-3}$ and $0.418 \mathrm{~m}^{3} \cdot \mathrm{m}^{-3}$ were noticed in the aggregates from combination "D3", whereas the lowest bulk density and the highest porosity, respectively, $1.20 \mathrm{Mg} \cdot \mathrm{m}^{-3}$ and $0.540 \mathrm{~m}^{3} \cdot \mathrm{m}^{-3}-$ in the 
aggregates from „B0” combination. Similar results were obtained by Ismail (2013). Variability of both properties in combinations from the same soil was very minor, usually statistically insignificant, independent from EM-A dose (Table 1).

Resistance to dynamic and static water action, as well as, most importantly, the state of secondary aggregation after the destruction of primary aggregation, are crucial traits of mineral soils (Rząsa and Owczarzak 2004). Destructive water action is connected with the energy of raindrops (dynamic action) or recurring processes of wetting and drying (static action). Both types of destructive actions often happen at the same time e.g. during heavy rain (Owczarzak 2002). Resistance to dynamic water action was between 5.08 (D3) and $38.67 \mathrm{~J} \cdot 10^{-2}$ (B1) (Table 2), whereas to static actions - between 138 (D2 - black earths; sandy loam) and $14400 \mathrm{~s}$ (A - black earths, loam and B black earths; silty loam) combinations-(Table 3 ). In the case of static water action, aggregates underwent only partial destruction in all "A" and "B" combinations. The results showed that the application of EM-A did not have a significant impact on water resistance of aggregates (Table 2 and 3 ). It is proved by minimal differences and randomness of the dissolution of these traits within combinations in one soil. However, different than presented in the paper conclusions were drawn by Mrugalska et al. (2009) and Feeney et al. (2006). The influence of soil microorganisms on structure stability was also the subject of research by Cosentino et al. (2006). The authors noticed a clear relationship between the content of labile form of organic matter (which among all contains organisms' biomass) and stability of aggregates. Nevertheless, these authors did not apply additional doses of microorganisms, yet only observed the impact of the addition of straw on microbiological activity and stability of aggregates. Resistance to both static and dynamic water actions does not determine soil's structure forming abilities (Rząsa and Owczarzak 2004). Yet sometimes, aggregates which show lower water resistance, having been dissolved, offer much more favorable quantity and quality dissolution of secondary aggregates (the state of secondary aggregation) (Rząsa and Owczarzak 2004). The state of secondary aggregation (percentage content of aggregation $>0.25 \mathrm{~mm}$ ) in different soil variants after dynamic water resistance ranged between $55.59-57.02 \%$ - soil A, 56.16-58.40\% - soil B, $55.38-59.77 \%$ - soil C and $22.34-25.56 \%$ - soil D (Table 2). Secondary aggregation after static water action was very similar: $54.69-58.70 \%$ - soil A, $56.62-59.70 \%$ - soil B, 51.67-55.60\% - soil C, 29.30$32.51 \%$ - soil D (Table 3 ). The results show usually insignificant, little from a practical point of view, an increase in the number of secondary aggregates. The most favorable secondary aggregation was usually observed in combinations with the highest dose of EM-A. Positive influence of effective microorganisms on the state of secondary aggregation after dynamic as well as static water action, was however observed by other authors (i.e., Mrugalska et al. 2009). According to Rząsa and Owczarzak (2004), what is important,

TABLE 2. Dynamic water resistance of the modelled aggregates, and secondary aggregation after dynamic water action

\begin{tabular}{|c|c|c|c|c|c|c|c|c|}
\hline \multirow{3}{*}{$\begin{array}{l}\text { Combi- } \\
\text { nation }\end{array}$} & \multirow{3}{*}{$\begin{array}{l}\text { Dynamic } \\
\text { water } \\
\text { resistance } \\
{\left[\mathrm{J} \cdot 10^{-2}\right]}\end{array}$} & \multicolumn{7}{|c|}{ Secondary aggregation after dynamic water action [\%] } \\
\hline & & \multicolumn{6}{|c|}{ Aggregate fractions $[\mathrm{mm}]$} & \multirow{2}{*}{$\begin{array}{l}\text { Sum of the aggregates } \\
>0.25 \mathrm{~mm} \\
{[\%]}\end{array}$} \\
\hline & & $>7$ & $7-5$ & $5-3$ & $3-1$ & $1-0.5$ & $0.5-0.25$ & \\
\hline A0 & $6.98 \mathrm{a}$ & $0.00 \mathrm{a}$ & $0.00 \mathrm{a}$ & $4.07 \mathrm{c}$ & $14.78 \mathrm{c}$ & $20.08 \mathrm{a}$ & $16.66 a$ & $55.59 \mathrm{a}$ \\
\hline A1 & $7.13 \mathrm{a}$ & $0.00 \mathrm{a}$ & $0.00 \mathrm{a}$ & $4.92 \mathrm{c}$ & $11.59 \mathrm{a}$ & $20.85 a$ & $18.97 \mathrm{~b}$ & $56.33 \mathrm{a}$ \\
\hline A2 & $6.64 a$ & $0.00 \mathrm{a}$ & $0.00 \mathrm{a}$ & $2.01 \mathrm{a}$ & $13.64 b$ & $21.85 \mathrm{~b}$ & $19.52 b$ & $57.02 \mathrm{a}$ \\
\hline A 3 & $6.53 \mathrm{a}$ & $0.00 \mathrm{a}$ & $0.00 \mathrm{a}$ & $3.38 \mathrm{~b}$ & $12.58 \mathrm{~b}$ & $21.27 \mathrm{~b}$ & $19.48 b$ & $56.71 \mathrm{a}$ \\
\hline B0 & $36.54 a$ & $0.00 \mathrm{a}$ & $3.40 \mathrm{~b}$ & $11.70 \mathrm{a}$ & $14.46 \mathrm{~b}$ & $17.31 \mathrm{~b}$ & $9.22 \mathrm{a}$ & $56.16 \mathrm{a}$ \\
\hline B1 & $38.67 \mathrm{~b}$ & $0.00 \mathrm{a}$ & $4.28 \mathrm{~b}$ & $10.73 a$ & $11.70 \mathrm{a}$ & $19.02 \mathrm{c}$ & $10.96 b$ & $56.69 \mathrm{a}$ \\
\hline B2 & $34.41 \mathrm{a}$ & $0.00 \mathrm{a}$ & $2.19 \mathrm{a}$ & $14.70 \mathrm{c}$ & $14.26 \mathrm{~b}$ & $15.71 \mathrm{a}$ & $10.62 b$ & $57.51 \mathrm{a}$ \\
\hline B3 & $33.64 \mathrm{a}$ & $0.00 \mathrm{a}$ & $5.92 \mathrm{c}$ & $12.97 \mathrm{~b}$ & $14.24 b$ & $15.68 \mathrm{a}$ & $9.59 \mathrm{a}$ & $58.40 \mathrm{~b}$ \\
\hline $\mathrm{C} 0$ & $24.48 \mathrm{a}$ & $0.00 \mathrm{a}$ & $0.00 \mathrm{a}$ & $4.74 \mathrm{a}$ & $18.99 \mathrm{a}$ & $20.24 a$ & $11.41 \mathrm{a}$ & $55.38 \mathrm{a}$ \\
\hline $\mathrm{C} 1$ & $23.94 a$ & $0.00 \mathrm{a}$ & $0.00 \mathrm{a}$ & $5.34 b$ & $19.04 \mathrm{ab}$ & $22.05 \mathrm{a}$ & $11.69 a$ & $58.12 b$ \\
\hline $\mathrm{C} 2$ & $22.19 \mathrm{a}$ & $0.00 \mathrm{a}$ & $0.00 \mathrm{a}$ & $4.86 a$ & $19.01 \mathrm{a}$ & $21.21 \mathrm{a}$ & $10.66 \mathrm{a}$ & $55.74 \mathrm{a}$ \\
\hline $\mathrm{C} 3$ & $21.32 \mathrm{a}$ & $0.00 \mathrm{a}$ & $0.00 \mathrm{a}$ & $5.26 \mathrm{~b}$ & $18.44 \mathrm{a}$ & $23.38 \mathrm{~b}$ & $12.69 \mathrm{~b}$ & $59.77 \mathrm{c}$ \\
\hline D0 & $6.61 \mathrm{a}$ & $0.00 \mathrm{a}$ & $0.00 \mathrm{a}$ & $0.00 \mathrm{a}$ & $1.86 \mathrm{a}$ & $7.90 \mathrm{a}$ & $12.58 \mathrm{a}$ & $22.34 \mathrm{a}$ \\
\hline D1 & $5.59 \mathrm{a}$ & $0.00 \mathrm{a}$ & $0.00 \mathrm{a}$ & $0.00 \mathrm{a}$ & $1.78 \mathrm{a}$ & $8.10 \mathrm{a}$ & $13.49 b$ & $23.37 \mathrm{a}$ \\
\hline D2 & $5.12 \mathrm{a}$ & $0.00 \mathrm{a}$ & $0.00 \mathrm{a}$ & $0.00 \mathrm{a}$ & $2.04 \mathrm{a}$ & $7.77 \mathrm{a}$ & $13.09 b$ & $22.90 \mathrm{a}$ \\
\hline D3 & $5.08 \mathrm{a}$ & $0.00 \mathrm{a}$ & $0.00 \mathrm{a}$ & $0.00 \mathrm{a}$ & $1.93 \mathrm{a}$ & $9.25 b$ & $14.38 \mathrm{c}$ & $25.56 \mathrm{~b}$ \\
\hline
\end{tabular}

Mean values with the same letter do not differ significantly (see Material and Methods). 
TABLE 3. Static water resistance of the modelled aggregates and secondary aggregation after static water action

\begin{tabular}{|c|c|c|c|c|c|c|c|c|}
\hline \multirow{3}{*}{$\begin{array}{l}\text { Combi- } \\
\text { nation }\end{array}$} & \multirow{3}{*}{$\begin{array}{l}\text { Static } \\
\text { water } \\
\text { resistance } \\
{[\mathrm{s}]}\end{array}$} & \multicolumn{7}{|c|}{ Secondary aggregation after static water action [\%] } \\
\hline & & \multicolumn{6}{|c|}{ Aggregate fractions $[\mathrm{mm}]$} & \multirow{2}{*}{$\begin{array}{l}\text { Sum of the aggregates } \\
->0.25 \mathrm{~mm} \\
{[\%]}\end{array}$} \\
\hline & & $>7$ & $7-5$ & $5-3$ & $3-1$ & $1-0.5$ & $0.5-0.25$ & \\
\hline A 0 & $14400 * a$ & $0.00 \mathrm{a}$ & $1.38 \mathrm{a}$ & $4.04 \mathrm{c}$ & $18.02 \mathrm{~b}$ & $19.84 a$ & $11.41 \mathrm{a}$ & $54.69 a$ \\
\hline A1 & $14400 * a$ & $0.00 \mathrm{a}$ & $1.30 \mathrm{a}$ & $2.84 b$ & $16.58 \mathrm{a}$ & $18.57 \mathrm{a}$ & $16.17 \mathrm{c}$ & $55.46 \mathrm{a}$ \\
\hline $\mathrm{A} 2$ & $14400 * a$ & $0.00 \mathrm{a}$ & $1.45 \mathrm{a}$ & $2.70 \mathrm{~b}$ & $17.30 \mathrm{a}$ & $20.58 b$ & $14.48 b$ & $56.51 \mathrm{a}$ \\
\hline A3 & $14400 * \mathrm{a}$ & $0.00 \mathrm{a}$ & $1.32 \mathrm{a}$ & $1.65 \mathrm{a}$ & $16.77 \mathrm{a}$ & $24.92 \mathrm{c}$ & $14.04 \mathrm{~b}$ & $58.70 \mathrm{~b}$ \\
\hline B0 & $14400 * a$ & $0.00 \mathrm{a}$ & $3.23 b$ & $13.32 \mathrm{a}$ & $15.11 b$ & $15.61 \mathrm{a}$ & $9.35 \mathrm{a}$ & $56.62 \mathrm{a}$ \\
\hline B1 & $14400 * \mathrm{a}$ & $0.00 \mathrm{a}$ & $3.39 b$ & $12.60 \mathrm{a}$ & $15.69 b$ & $15.64 \mathrm{a}$ & $9.88 \mathrm{a}$ & $57.20 \mathrm{a}$ \\
\hline B2 & $14400 * a$ & $0.00 \mathrm{a}$ & $2.38 \mathrm{a}$ & $15.56 b$ & $15.34 b$ & $15.74 a$ & $8.65 a$ & $57.67 \mathrm{a}$ \\
\hline $\mathrm{B} 3$ & $14400 * \mathrm{a}$ & $0.00 \mathrm{a}$ & $3.57 \mathrm{~b}$ & $14.64 b$ & $13.55 \mathrm{a}$ & $19.01 \mathrm{~b}$ & $8.93 \mathrm{a}$ & $59.70 \mathrm{~b}$ \\
\hline $\mathrm{C} 0$ & $837 \mathrm{a}$ & $0.00 \mathrm{a}$ & $0.00 \mathrm{a}$ & $0.00 \mathrm{a}$ & $25.41 \mathrm{a}$ & $18.88 \mathrm{a}$ & $7.38 \mathrm{a}$ & $51.67 \mathrm{a}$ \\
\hline $\mathrm{C} 1$ & $910 \mathrm{~b}$ & $0.00 \mathrm{a}$ & $0.00 \mathrm{a}$ & $0.00 \mathrm{a}$ & $24.47 \mathrm{a}$ & $19.09 a$ & $8.96 \mathrm{a}$ & $52.52 \mathrm{a}$ \\
\hline $\mathrm{C} 2$ & $827 \mathrm{a}$ & $0.00 \mathrm{a}$ & $0.00 \mathrm{a}$ & $0.00 \mathrm{a}$ & $25.91 \mathrm{a}$ & $19.56 \mathrm{a}$ & $10.13 b$ & $55.60 \mathrm{~b}$ \\
\hline $\mathrm{C} 3$ & $818 \mathrm{a}$ & $0.00 \mathrm{a}$ & $0.00 \mathrm{a}$ & $0.00 \mathrm{a}$ & $26.56 \mathrm{a}$ & $19.25 \mathrm{a}$ & $7.72 \mathrm{a}$ & $53.53 b$ \\
\hline D0 & $167 \mathrm{~b}$ & $0.00 \mathrm{a}$ & $0.00 \mathrm{a}$ & $0.00 \mathrm{a}$ & $1.57 \mathrm{a}$ & $14.64 \mathrm{a}$ & $13.09 \mathrm{a}$ & $29.30 \mathrm{a}$ \\
\hline D1 & $178 b$ & $0.00 \mathrm{a}$ & $0.00 \mathrm{a}$ & $0.00 \mathrm{a}$ & $1.95 \mathrm{a}$ & $14.43 \mathrm{a}$ & $13.51 \mathrm{a}$ & $29.89 a$ \\
\hline D2 & $138 \mathrm{a}$ & $0.00 \mathrm{a}$ & $0.00 \mathrm{a}$ & $0.00 \mathrm{a}$ & $2.44 b$ & $14.11 \mathrm{a}$ & $13.97 \mathrm{a}$ & $30.52 \mathrm{a}$ \\
\hline D3 & $142 \mathrm{a}$ & $0.00 \mathrm{a}$ & $0.00 \mathrm{a}$ & $0.00 \mathrm{a}$ & $1.91 \mathrm{a}$ & $15.06 \mathrm{a}$ & $15.54 b$ & $32.51 \mathrm{~b}$ \\
\hline
\end{tabular}

*Aggregates were only partially destroyed. Mean values with the same letter do not differ significantly (see Material and Methods).

is not only a total number of secondary aggregates, but also the character of their disaggregation, i.e. percentage amount of various fractions. As a result of dynamic water action, primary aggregates disintegrated in fraction of aggregates of: 5-3 mm, 3-1 mm, $1-0.5 \mathrm{~mm}, 0.5-0.25 \mathrm{~mm}$. Secondary aggregates of $7-5 \mathrm{~mm}$ rarely appeared, and there were no aggregates bigger then $7 \mathrm{~mm}$. In case of soils $\mathrm{A}, \mathrm{B}$ and $\mathrm{C}$, the contribution of the aggregates of $1-0.5 \mathrm{~mm}$ was the largest, whereas in soil D - fraction of $0.5-0.25 \mathrm{~mm}$ was dominant (Table 2). Distribution of secondary aggregation after static water action was similar. Among secondary aggregates, fraction of $1-0.5 \mathrm{~mm}$ was usually dominant. Secondary aggregates of 5-3 mm and $7-5 \mathrm{~mm}$ rarely appeared, and there were no aggregates bigger than $7 \mathrm{~mm}$ (Table 3). Application of EM-A usually did not have a significant impact on the above-mentioned properties. A full analysis of the influence of EM-A preparation on the structure cannot omit their water properties and, most importantly their minimal and maximal capillary water capacity. The effect of EM-A solution on these traits was also studied by Mrugalska et al. (2009). Minimal capillary water capacity ranged between $40.01 \% \mathrm{v}$ (combination D1) $-50.84 \%$ v (combination B2) (Table 4). Maximal capillary water capacity was higher by about $3-17 \% \mathrm{v}$. It was also noticed that it exceeded total primary porosity by $1-11 \% \mathrm{v}$. It means that the collected aggregates boosted their capacity. Such a phenomenon was observed by, among others, Mrugalska et al. (2009) and Gajewski et al. (2013). A similar, triaxial swelling of aggregates was described by Rząsa and Owczarzak (2004). No positive effect of EM-A on the presented traits was observed. Slight variability of those parameters was statistically insignificant. However, a minor increase on capillary water capacities as a result of EM application was observed by Valarini et al. (2003). Mrugalska et al. (2009) got similar conclusions. The authors found a significant improvement of $\mathrm{Vk}$ min and $\mathrm{Vk}$ max.

TABLE 4. Minimum $\left(\mathrm{V}_{\mathrm{kmin}}\right)$ and maximum $\left(\mathrm{V}_{\mathrm{kmax}}\right)$ capillary water capacity

\begin{tabular}{lcc}
\hline Combination & \multicolumn{2}{c}{ Capillary capacity [\%v] } \\
\cline { 2 - 3 } & $\mathrm{V}_{\mathrm{kmin}}$ & $\mathrm{V}_{\mathrm{kmmx}}$ \\
\hline $\mathrm{A} 0$ & $43.57 \mathrm{a}$ & $55.77 \mathrm{a}$ \\
$\mathrm{A} 1$ & $42.56 \mathrm{a}$ & $58.43 \mathrm{~b}$ \\
$\mathrm{~A} 2$ & $42.01 \mathrm{a}$ & $59.45 \mathrm{~b}$ \\
$\mathrm{~A} 3$ & $44.12 \mathrm{a}$ & $58.15 \mathrm{~b}$ \\
\hline B0 & $50.12 \mathrm{a}$ & $59.27 \mathrm{~b}$ \\
B1 & $49.49 \mathrm{a}$ & $57.14 \mathrm{a}$ \\
B2 & $50.84 \mathrm{a}$ & $57.36 \mathrm{a}$ \\
B3 & $48.66 \mathrm{a}$ & $58.90 \mathrm{~b}$ \\
\hline C0 & $46.57 \mathrm{a}$ & $57.86 \mathrm{a}$ \\
C1 & $45.43 \mathrm{a}$ & $57.54 \mathrm{a}$ \\
C2 & $46.34 \mathrm{a}$ & $56.29 \mathrm{a}$ \\
C3 & $44.93 \mathrm{a}$ & $57.58 \mathrm{a}$ \\
\hline D0 & $41.12 \mathrm{a}$ & $44.23 \mathrm{a}$ \\
D1 & $40.01 \mathrm{a}$ & $46.02 \mathrm{~b}$ \\
D2 & $41.22 \mathrm{a}$ & $44.50 \mathrm{a}$ \\
D3 & $40.98 \mathrm{a}$ & $44.49 \mathrm{a}$ \\
\hline
\end{tabular}

Mean values with the same letter do not differ significantly (see Material and Methods). 
Most of the presented results oppose the information about a positive influence of EM-A on the state of the structure. The opposite opinion show Khaliq et al. (2006) and Valarini et al. (2003). Some authors make attempts to find out the reasons for inefficiency of microbial biopreparates (van Veen et al. 1997). They suggest that one of the basic problems which appear at the trial of implanting the soil with microorganisms which are new and not known for the ecosystem is the resistance to implanting artificial microorganisms. Pare et al. (1999) claims that the applied microorganisms cannot stand the competition of so called natural microbiocenose. Some authors (Cóndor Golec et al. 2007) pay attention to the fact that the amount of the EM applied into the soil is considerably lower than the number of natural microbioicenose and the disruption of ecological balance as a result of the application of the solution - very short-term. The same authors suggest that the effect of EM application may be much more visible in soils of lower content of microorganisms, e.g. in tropical soils. It is also claimed by Mayer et al. (2010). It is definitely worth to ask: what influence can the quantity and quality of organic matter have on the applied microorganisms? What will be the reaction of soil to simultaneous application of EM-A and addition of organic matter? Would it cause a different reaction of soil? Advantages of simultaneous EM-A and organic matter addition was noticed by Khaliq et al. (2006); studies have been also carried out by Gajewski et al. (2011) and Kaczmarek et al. (2012). Their results, however, did not bring a clear answer as the effect of EM activity depended strongly on the type of the added organic matter.

\section{SUMMARY}

Presented results tackled mainly a very important soil-forming factor, i.e. microorganisms. A trial has been undertaken in order to assess the influence of an added selected "portion" of microorganisms on the total carbon content and the state of mineral soils structure. The results showed that the application of EM-A preparation usually did not have a significant impact on the analyzed properties and parameters. It is difficult to determine the reason for the lack of positive action of the solution's application. Perhaps, effective microorganisms encountered a strong negative ecosystem. Also, it is highly possible that their number, even in high doses (from an agrotechnical point of view) was too low to cause any changes in the natural biocenosis.

\section{REFERENCES}

Cosentino D., Chenu C., Le Bissonnais Y., 2006. Aggregate stability and microbial community dynamics under dryingwetting cycles in a silt loam soil. Soil Biology and Biochemistry 38: 2053-2062.

Cóndor Golec A.F., González Pérez P., Lokare C., 2007. Effective Microorganisms: Myth or reality? Revista Preuana de Biologia 14(2): 315-319.

FAO: Guidelines for soil profile description. Land and Water Development Division. 1977. FAO. Rome: 1-66.

Feeney D.S., Hallet P.D., Sheena R., Bengough A.G. White N.A., Young I.M., 2006. Impact of fungal and bacterial biocides on microbial induced water repellency in arable soil. Geoderma 135: 72-80.

Fierer N., Schimel J.P., Holden P.A., 2003. Influence of drying rewetting frequency on soil bacterial community structure. Microbial Ecology 45: 63-71.

Gajewski P., Kaczmarek Z., Owczarzak. W., Mrugalska L., 2011. Wpływ efektywnych mikroorganizmów na wybrane właściwości fizyczne i wodne oraz stan struktury poziomu ornopróchnicznego gleb mineralnych, przy zróżnicowanej zawartości w nich materii organicznej. Część II. Stan struktury. Journal of Research and Applications in Agricultural Engineering 56(3): 83-87.

Gajewski P., Kaczmarek Z., Owczarzak W., Jakubus M., Mocek A., 2013. Wpływ dodatków organicznych oraz preparatu EM-A na właściwości fizyczne, chemiczne oraz stan struktury poziomu orno-próchnicznego gleby uprawnej. Część III. Stan struktury. Journal of Research and Applications in Agricultural Engineering 58(3): 119-123.

Higa T., 2003. Rewolucja w ochronie naszej planety. Fundacja Rozwój SGGW, Warszawa.

Ismail S.M., 2013. Influence of effective microorganisms and green manure on soil properties and productivity of pearl millet alfalfa grown on sandy loam in Saudi Arabia. African Journal of Microbiology Research 7(5): 375-382.

IUSS Working Group WRB, 2015. World reference base for soil resources 2014, update 2015. International Soil Classification System for Naming Soil and Creating Legends for Soil Maps. Food and Agriculture Organization of the United Nations, Rome: 190 pp.

Kaczmarek Z., Owczarzak W., Mrugalska L., Grzelak M., 2007. Wpływ efektywnych mikroorganizmów na wybrane właściwości fizyczne i wodne poziomów orno próchnicznych gleb mineralnych. Journal of Research and Applications in Agricultural Engineering 52 (3): 73-77.

Kaczmarek Z., Wolna-Maruwka A., Jakubus M., 2008. Zmiany liczebności wybranych grup drobnoustrojów glebowych oraz aktywności enzymatycznej w glebie inokulowanej efektywnymi mikroorganizmami (EM). Journal of Research and Applications in Agricultural Engineering 53 (3): 122-127.

Kaczmarek Z., Kruk K., Gajewski.P., Jakubus M., 2012. Wpływ dodatków osadu i kompostu komunalnego oraz efektywnych mikroorganizmów na wybrane właściwości poziomu ornopróchnicznego gleby mineralnej. Część I. Właściwości fizyczne i wodne. Journal of Research and Applications in Agricultural Engineering 57(3): 186-189.

Khaliq A., Kaleem A., Hussain T., 2006. Effects of integrated use of organic and inorganic nutrient sources with effective 
microorganisms (EM) on seed cotton yield in Pakistan. Bioresource Technology 97: 967-972.

Mayer J., Scheid S., Widmer F., Fileßbach A., Oberholzer H.R., 2010. How effective are "Effective microorganisms ${ }^{\circledR}(E M) "$ ? Results from a field study in temperate climate. Applied Soil Ecology 46 (2): 230-239.

Mrugalska L., Owczarzak W., Kaczmarek Z., 2009. Wpływ efektywnych mikroorganizmów na kształtowanie struktury gleb w doświadczeniu inkubacyjnym. Journal of Research and Applications in Agricultural Engineering 54(4): 26-31.

Neergaard-Bearden B., Petersen L., 2000. Influence of arbuscular mycorrhizal fungi on soil structure and aggregate stability of a vertisol. Plant and Soil 218: 173-183.

Owczarzak W., 2002. Struktura gleb mineralnych Polski - badania modelowe. Roczniki Akademii Rolniczej w Poznaniu, Rozprawy Naukowe 328: 183 pp.

Pare T., Dinel H., Moulin A.P., Townley-Smith L., 1999. Organic matter quality and structural stability of Black Chernozemic soil under different manure and tillage practices. Geoderma 91: 311-326.

Polish Soil Classification (Systematyka gleb Polski), 2011. Roczniki Gleboznawcze - Soil Science Annual 62(3): 1-193 (in Polish with English summary).

Roldán A., Garcia- Orenes F., Lax A., 1994. An incubation experiment to determine factors involving aggregation changes in an arid soil receiving urban refuse. Soil Biology and Biochemistry 26: 1699-1707.

Rząsa S., Owczarzak W., Mocek A., 1999. Problemy odwodnieniowej degradacji gleb uprawnych w rejonach kopalnictwa odkrywkowego na Niżu Środkowopolskim, Wydawnictwo Akademii Rolniczej w Poznaniu: 394 pp.

Rząsa S. and Owczarzak W., 1983. Modeling of soil structure and examination methods of water resistance, capillary rise and mechanical strength of soil aggregates. Annales of Poznań Agriculture University, Scientific Disserations: 135 pp.

Rząsa. S., Owczarzak W., 2004. Struktura gleb mineralnych. Wydawnictwo Akademii Rolniczej im. A. Cieszkowskiego w Poznaniu: 394 pp.
Schenck zu Schweinsberg-Mickan M., Müller T., 2009. Impact of effective microorganisms and other biofertilizers on soil microbial characteristics, organic-matter decomposition, and plant growth. Journal of Plant Nutrition and Soil Science 172: 704-712.

Schlecht-Pietsch S., Wagner U., Anderson T.H., 1994. Changes in composition of soil polysaccharides and aggregate stability after carbon amendments to different textured soils. Applied Soil Ecology 1: 145-154.

Świętochowski B., Jabłoński B., Radomska M., Krężel R., 1996. Ogólna uprawa roli i roślin. PWRiL, Warszawa: 405 pp.

Tołoczko W., Trawczyńska A., Niewiadomski A., 2009. Zawartość związków próchnicznych w glebach nawożonych preparatem EM. Soil Science Annual 60 (1): 97-101.

Valarini P.J., Alvarez D., Gascó J.M., Guerrero F., Tokeshi H., 2003. Assesment of soil properties by organic matter and EM- microorganism incorporation. Revista Brasileira de Cięncia do Solo 27: 519-525.

Van Reeuwijk L.P., 2002. Procedures for soil analysis. International Soil Reference and Information Centre, Wageningen, Netherlands: $100 \mathrm{pp}$.

Van Veen J.A., van Overbeek L.S., van Elsas J.D., 1997. Fate and activity of Microorganisms Introduced into Soil. Microbiology and Molecular Biology Reviews 61(2): 121-135.

van Vliet P.C.J., Bloem J., de Goede R.G.M., 2006. Microbial diversity, nitrogen loss and grass production after addition of effective microogranisms (R) (EM) to slurry manure. Applied Soil Ecology 32: 188-198.

Zajączkowski P., Sowiński W., 2001. Jaka gleba taki plon. Technologia Efektywnych Mikroorganizmów. Biuletyn informacyjny, Greenland, Technologia EM, Puławy.

Zydlik P., Zydlik Z., 2008. Impact of biological effective microorganisms (EM) preparations on some physico-chemical properties of soil and the vegetative growth of apple-tree rootstocks. Nauka Przyroda Technologie 2 (1).

Received: June 2, 2016

Accepted: January 16, 2017

Associated editor: J. Rejman

\section{Wpływ preparatu EM-A na właściwości struktury różnych gleb mineralnych}

Streszczenie: Celem pracy była ocena wpływu preparatu EM-A na właściwości struktury gleb o średnim i ciężkim uziarnieniu. Materiał glebowy wykorzystany do założenia doświadczenia inkubacyjnego pobrano z poziomów orno-próchnicznych czterech gleb mineralnych. Były to: czarne ziemie typowe (Gleyic Chernozem) (gleby A,B i D) oraz mada właściwa (Haplic Fluvisol) (gleba C). Doświadczenie przeprowadzono w pojemnikach o objętości $2000 \mathrm{~cm}^{3}$, w których umieszczono materiał glebowy o masie około $3 \mathrm{~kg}$, a następnie dodano trzy dawki roztworu EM-A. Po 12-miesięcznej inkubacji, wycięto modele agregatów o objętości $1 \mathrm{~cm}^{3}$. Oznaczono dla nich podstawowe właściwości fizyczne (gęstość, porowatość) oraz parametry charakteryzujące strukturę takie, jak: dynamiczną i statyczną wodoodporność, agregację wtórną po dynamicznym i statycznym działaniu wody, pojemność kapilarną agregatów. W przypadku większości analizowanych cech wpływ preparatu EM-A był nieistotny.

Stowa kluczowe: preparat EM-A, agregacja wtórna, minimalna i maksymalna pojemność wodna. 